\title{
Retail Workforce Sizing Strategy for Enhancing Service Delivery and Store Performance
}

Pankaj M. Madhani, ICFAI Business School, India

(iD) https://orcid.org/0000-0002-8810-3201

\begin{abstract}
The retail workforce is a strategic lever of the retailer for improving sales growth, market share, and profitability. With optimal retail workforce sizing and structure, customers would get prompt sales assistance and service, shelves should be replenished in a timely manner, store employees should be neither idle nor overstretched, and compensation costs should be managed effectively. Undersizing may hurt retailers in the long run as it affects merchandising capability and customer services, which ultimately hurt store sales and profits. Retail workforce optimization keeps store employees happy, improves customer service, and reduces opportunity costs of lost sales. The research provides various frameworks that outline the impact of undersizing in retail stores on sales and profitability and provides a methodology to determine the optimal workforce size. The research also provides an illustration with various scenarios to investigate whether a retail store is understaffed and calculates the financial impact of undersizing on revenue and profitability.
\end{abstract}

\section{KEYWORDS}

Brick-and-Mortar (B\&M) Retailer, Compensation Costs, Customer Satisfaction, Customer Services, Retail Store Environment, Retail Store Performance, Retail Workforce Size

\section{INTRODUCTION}

No matter how you slice it in the retail business, payroll is one of the most important parts of overhead, and overhead is one of the most crucial things you have to fight to maintain your profit margins. That was true then, and it is still true today. - Sam Walton, Walmart Founder (Walton\& Huey, 1993) 
In the highly competitive retail environment, many brick-and-mortar $(\mathrm{B} \& \mathrm{M})$ retailers consider instore experience critical to converting incoming traffic into sales and future visits. Superior in-store experience requires having not only inventory in place but also a skilled store workforce to ensure an efficient and pleasant visit for the customers. The retail workforce is a critical component to the overall success of the traditional B\&M retailer's goals and objectives. Increased competition from online shopping threatens the very existence of many traditional retailers (i.e., traditional B\&M stores). U.S. Department of Commerce quarterly eCommerce figures show that consumers spent $\$ 601.75$ billion online with U.S. merchants in 2019, up 14.9\% from $\$ 523.64$ billion the prior year (Young, 2020). Nearly 8,000 retail U.S. stores closed in 2017, according to investment banking firm UBS (Stock sector, 2018). However, traditional retail stores still hold a key advantage over online competitors: the ability to provide a memorable in-store shopping experience and fantastic service levels on the shop floor. Hence, retailers must enhance the customer in-store experience to better compete with online retail.

For traditional B\&M retailers, conventional methods of competing through convenience, assortment, and pricing are largely ineffective against online retailers who outperform them in these dimensions. In this scenario, retailers should use service as a way to distinguish themselves from online retailers. A positive customer experience has a significant impact on customer retention and purchase behavior (Bapat \& Thanigan, 2016). Hence, retail stores require better control of the instore environment with effective management of the retail workforce. The presenceof frontline store associates and human interaction can play a pivotal role when competing against online retailers (Rajamma et al., 2007). Research by Salesforce shows that $75 \%$ of consumers say it's absolutely critical or very important to interact with a salesperson who is available when needed during a shopping trip (Salesforce, 2019).

The role of frontline store employees is, more than ever, crucial to the success of retailers (Ifie, 2014). However, workforce-related expenses (i.e., compensation and benefits costs) account for a significant portion of a retail stores' operating expense (Ton, 2009). Labor is the biggest component of selling, general, and administrative (SG\&A) expenses for 10 of the largest U.S. grocers and estimated at $14 \%$ of sales on average (L.E.K. Consulting, 2017). Therefore, retailers need to balance the need to increase sales by deploying more workforces for providing better services to customers against the need to control retail workforce expenses that can increase commensurately.

Research works in this direction and discusses the contribution of the retail workforce in enhancing service delivery and profitability of retailers. It also explores the traditional retail workforce sizing approach and highlights its limitations in determining optimal retail workforce size. Hence, such a sizing approach leads to either undersizing or oversizing of the retail workforce. Prior research suggests that both undersizing as well as oversizing of workforce results in sub-optimal retail store performance (Madhani, 2021c). . The following research questions are being investigated:

- What are the issues inherent with undersizing as well as oversizing of the retail workforce and how to overcome it?

- How to calculate optimal retail workforce sizing with an analytical approach?

This research is unique in that it shed light on both dimensions of retail store performance i.e., service delivery and optimal size of the retail workforce to facilitate it. The research underscores a crucial role of retail store employees in enhancing customer satisfaction and store experience and develops various frameworks for synthesizing value creation processes for retailers. 


\section{LITERATURE REVIEW}

Retailers are directly impacted by the distinctive and constantly changing behavior of customers, and hence they require rapid responses to meet ever-changing customer needs (Madhani, 2020). In retail stores, an adequate workforce level enhances service quality. Service quality is an important determinant of customer satisfaction. Retail store employees or associates play a critical role in driving customer satisfaction. Customer satisfaction leads to customer loyalty because it breeds attachment to the provider and motivates repurchase intentions (Madhani, 2019). A study finds that a positive experience with a retailer's staff increases customers' satisfaction by 33\% (InMoment, 2017). The traditional B\&M retail store is a critical step in the purchase journey as many customers desire a face to face interaction. According to a survey, just $32 \%$ of customers prefer to do their research in a physical retail store, but $53 \%$ prefer to purchase in a physical store. $40 \%$ of customers said that the in-store shopping experience would be made better by sales associates with a deep knowledge of the product (PWC, 2016).

Decreasing store labor is associated with a higher percentage of phantom products. Phantom stockouts occur when a product is available in the store but not on the right shelf (Fisher\& Raman, 2010). A one-standard-deviation increase in the percentage of phantom products is associated with a $1 \%$ decrease in-store sales which, translates to a loss of roughly $7 \%$ of the net income (assuming a $30 \%$ gross margin) generated by an average store (Raman et al., 2001). An increase in-store traffic would lead to more sales, as higher traffic provides more opportunities for sales conversion. However, in the absence of an adequate retail workforce, an increase in traffic could lead to higher crowding and a decrease in service quality, both of which could lead to lower store performance. Increased customer traffic variability in retail stores could lead to higher waiting time in queues, lower service quality, and result in higher levels of abandonment. Researchers found that increases in inter-day traffic variability are associated with lower sales per hour in stores (Perdikaki et al., 2012).

Retailing is a very labor-intensive industry as employee costs accounting for a considerable percentage of a retailer's administrative costs (Tang et al., 2014). Although retailers care deeply about providing high service levels to customers through the increased workforce in their stores, they are also wary about the workforce payroll expenses associated with this practice. SG\&A expenses, which consist largely of store employee payroll expenses, represented approximately $20 \%$ of retail sales (DeHoratius \& Ton, 2015). The retail workforce has a key role in the sales process; hence the right retail associates at the right time with the necessary skill may be critical to increase the conversion rate (defined as the ratio of the number of transactions to incoming traffic) at retail stores.

There is a positive association between store workforce and profits as store employees are an important contributor to the retail sales process (Ton, 2009). There are many drivers for retail performance, such as price, product, in-stock availability, and return policy but, the role of the sales associate is most crucial and above all of these drivers. The retail workforce is a key driver of store success, and hence retailers who elevate their retail workforces to a strategic level will gain competitive cost and service advantage. A well-trained and well-equipped retail associate is a critical part of the process to drive revenue, provide better shopping experiences, and create loyal customers.

When there aren't enough store associates, retail store sales don't reach their potential. Prior research for apparel retail chain's stores in the U.S. found that store managers were systematically understaffing or undersizing their stores. If they even slightly increased staffing levels, they would generate incremental sales that would outweigh the workforce costs (MIT study, 2017). Research shows that even a minor increase in staffing levels can increase retail store profit margins by 10 percent over a year (Ton, 2012). Retailers should align the store workforce with customer traffic and not transactions. Research suggests that better labor planning and execution would lead to superior store performance, and matching store labor to traffic is associated with greater basket values (Netessine et al., 2010).

There is a positive impact of retail workforce levels (i.e., size) and composition (i.e., structure) on inventory data quality as workforce effort affects store inventory record inaccuracy (Chuang \& Oliva, 
2015). When store employees have more time, they are less likely to make errors in activities, such as shelving merchandise or placing price tags on display shelves, and more likely to spend time with customers. Thus, sales are to be higher when products are shelved properly (Ton \& Raman, 2010) and store associates are available to help customers in the purchase process (Fisher et al., 2006). The retail workforce is a key to resolving execution issues (Raman et al., 2001) such as inventory record inaccuracy (DeHoratius \& Raman, 2007) and phantom stockouts at retailers (Ton \& Raman, 2010).

The performance of retail stores depends highly on the successful execution of store operation activities such as processing inventory, shelving merchandise, responding to customer queries, and completing the sales transaction. With optimal workforce size and structure, retail employees can shelve, replenish, and help customers find products more quickly, and fewer products are expected to be damaged or lost. Frontline store employees play a critical role in driving customer satisfaction and retail store performance (Arndt et al., 2006). Hence, retailers need an adequate and well-trained workforce as a long-term solution to stable profit margins. Customers may be more willing to visit a storewhen they expect a high service level (Dana \& Petruzzi, 2001). The importance of frontline store employees in the physical retail store is emphasized in prior research (Wiles, 2007; Korschun et al., 2014).

Despite substantial changes in retailing (e.g., methods and time of delivery, store locations, shopping habits, product offerings) (Grewal \& Levy, 2007), store associates continue to be the critical "sales messengers" mostly responsible for retailers' success. But it's not much of an advantage if retail stores can't deliver top customer service or manage their merchandise and store experiences activities dependent on having enough retail workforces on hand (Retail Dive Report, 2017). Effective management of store workforce is important to successful retail operations as store workforce performs all service-related tasks (e.g., check-out: returns: shopping assistance) (Fisher et al., 2006) and production-like tasks (i.e., in-store logistics) (Ton, 2009).

The benefits of having an adequate retail store workforce include providing an increased level of store assistance to customers and improving execution of store operational activities such as stocking shelves, tagging merchandise, and maintaining the overall store ambiance (Arndt et al., 2006), all of which lead to increased sales and profitability. For one retailer, right-sizing the staff in 168 stores over a period produced a $4.5 \%$ revenue increase and a nearly $\$ 7.4$ million annual profit increase: after accounting for the cost of the additional labor (Fisher et al., 2018). In many retail settings, customers do not expect or receive help from sales associates, and hence, poor customer-salesperson encounters can terminate consumers' shopping experiences (Fowler et al., 2007). Retail workforce-related issues considerably affect both customer satisfaction and sales (Fisher et al., 2007). The number or availability of retail associates is considered to be an important variable influencing consumers' responses towards stores (Kim \& Kim, 2012).

Customer service and employee training can have a positive impact on both customer satisfaction and sales (Fisher et al., 2016). The top-shelf service by store associates can make the difference between a customer making a purchase or walking out from a retail store in frustration. Deciding on the proper size (number of employees) and structure (effective mix of full-time, part-time or temporary employees) of the retail workforce is a strategic management issue because it has an important impact on a retailer's performance in terms of revenues and profits. It is clear from the literature review that there is a strong need for analyzing retail workforce sizing issues not only from cost containment perspectives but also from various service delivery tasks and activities in the store environment to enhance the overall performance of retailers.

Unlike retail stores' promotions and advertising budgets that can be altered by the corporate office from time to time, any change in the size and structure of the retail workforce requires meticulous planning. The size and structure of the retail workforce affect the store associates' morale, compensation practices used by retailers, and ultimately overall store performance. This study consists of two independent variables and a dependent variable. Optimal retail workforce size and structure (independent variables) are believed to directly positively influence the retail store performance 
(dependent variable). A review of the literature on the variables for this study and their relationships are explored. Both the independent and dependent variables of the study are analyzed to identify the relationship between variables. The research underscores the crucial role of the retail workforce in providing better customer experience, and enhancing store performance, and builds conceptual frameworks that can be empirically tested.

\section{Retail Workforce Management: Major Driverfor Enhancing Store Performance}

A retail workforce that is of the right size and structure are challenged but not overworked, connect with customers effectively, compensation costs are reasonable, and revenue, as well as the profitability of the retailer, is strong and thus, affects store associates, customers, and the retailer. An optimal mix of tangible and intangible rewards will enhance the performance of employees (i.e., increased employee engagement, satisfaction, and retention; productivity and quality of work) (Madhani, 2021b). The retail workforce is a strategic lever of the retailer for improving sales growth, market share, and profitability. Finding the perfect retail workforce size and structure for each store is both an art and science for a retailer but, once determined, it becomes the cornerstone of store performance (Figure 1).

Figure 1. Retail Workforce Management: Enhancing Store Performance (Source: Framework developed by the Author)

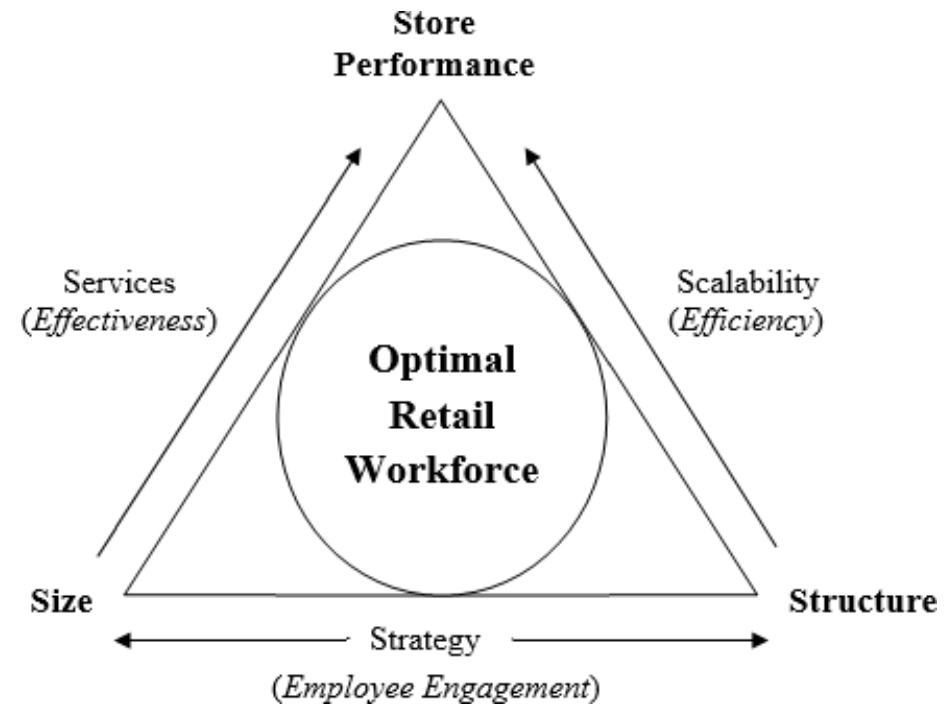

The retail workforce is an essential part of any retail operation's top and bottom line. Yet retailers tend to see store associates as an expense to be controlled rather than as a medium to provide better service for customers (Williams et al., 2018). Retailers that manage the store workforce most effectively convert that expense into an asset. Retailers that can predict the need for a store workforce, both quantitatively and qualitatively, in an environment of high uncertainty gain a great competitive advantage. After the cost of goods sold, expenses related to hiring, training, and employing store labor constitute by far the largest component of a retailer's costs, often accounting for 10 to $20 \%$ of sales and sometimes for more than $50 \%$ of operating costs (Chuang, \& Oliva, 2015). The retail store workforce falls into three categories depending upon the employment contract with the retailer: fulltime employees, part-time employees, and temporary or seasonal employees. Two primary reasons for deploying part-time or temporary staff are labor cost reduction and the ability to scale. Hence, retailers can easily, quickly, and with lower labor costs, upscale or downscale store workforce size. However, such an approach sacrifices the experience associated with full-time employees. 
The effective management of the retail workforce requires managing the workforce efficiently without compromising workforce effectiveness. The efficiency and effectiveness of the retail workforce depend on the following factors:

1. Retail workforce management practices in terms of size (e.g., undersized, oversized, or rightsized); structure (e.g.,mix of full time, part-time, temporary or seasonal employees); and strategy (e.g., profit maximization strategy, high road strategy, or good jobs strategy (Madhani, 2021a)) adopted for the workforce engagement (Figure 1);

2. The type of retail store (e.g., specialty store versus discount store);

3. The product characteristics of retail stores (e.g., electronics, fashion, furniture, or grocery);

4. The job description (e.g., store managers, sales associates, stockroom employees, etc.);

5. The number of hours available for each employee (e.g., the maximum number of hours available, break time, vacation time, etc.);

6. The level of store execution activities outsourced and sales-related service activities.

As shown in Figure 2, a retail store is a system in which customers, associates, and merchandise interact which each other over time to produce sales and profits for the retailer.

Figure 2. Retail Store Environment (Source: Framework developed by Author)

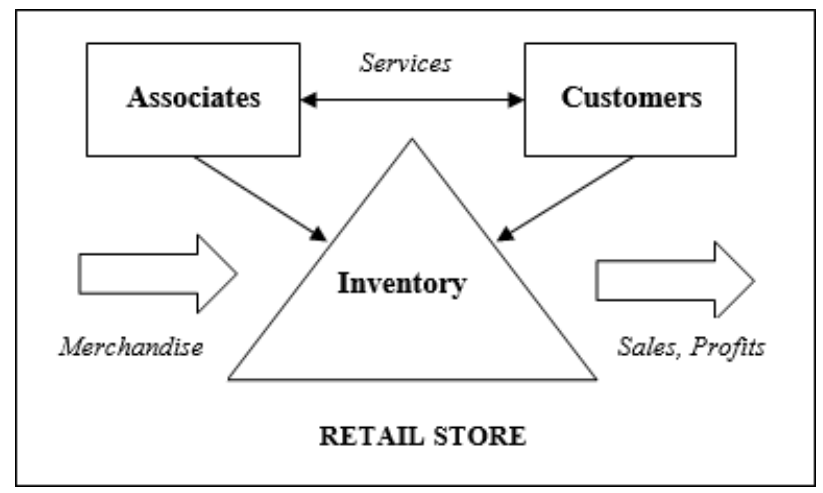

For retailers, it is challenging to predict exactly the size and structure of the workforce required for individual stores. Hence, major issues of retail workforce management are related to either undersizing or oversizing of the workforce as explained below.

\section{Retail Workforce Undersizing Issues}

Retailers are losing significant market share to online retailers. Online sales have grown at a much faster rate than traditional B\&M retail sales and account for $11.1 \%$ of total US retail sales as of 2019 (US Census, 2020). It's no secret that retailers are under constant pressure to decrease operational expenses. As they fight for survival in the era of online shopping, retailers are turning toan age-old strategy: cutting expenditures on store employees, i.e., undersizing the workforce. Retail workforce undersizing takes away the biggest advantage traditional retailstores have over e-tailers: associate with whom a customer can talk face-to-face. Undersizing by retailers for reducing compensation costs leads to poor customer service, a negative in-store experience, and in turn, lost sales and profits. A third of customers who experienced a problem at apparel stores were not able to locate sales help, and 6\% of all possible sales are lost because of lack of service, according to a report (Netessine et al., 2010). 
Many store managers are evaluated based on how well they manage workforce payroll expenses at their retail stores and hence, they tend to focus on lowering workforce payroll costs as the negative effect of having too little workforce is often difficult to quantify. Thus, many store managers place greater emphasis on minimizing retail workforce payroll expenses to meet short-term performance targets. Prior research also concludes that most retail stores tend to undersize their stores (Ton, 2009; Chuang \& Oliva, 2015).

Understaffing could lead to poor service quality for retail customers that can result inlower customer satisfaction (Oliva \& Sterman, 2001). It is also associated with a lower conversion rate as customers are turning back without purchasing and lower store traffic growth as customers are switching to competitors due to poor service. Dissatisfied customers may switch to competitors resulting in a loss of lifetime value from those customers (Heskett et al., 1994). Dissatisfied customers may also express their discontent at other forums, including social networking websites, causing retailers to worry about the negative word-of-mouth effect (Park et al., 2010). Many retailers tend to reduce the workforce in their stores because they view it as a short-term expense (Arndt et al., 2006). When sales are down, and the quarterly report is due, a common strategy for retailers to boost profits is to cut the store workforce. But temporary reductions in personnel or hours often become permanent or cyclical, and stores get caught in a downward spiral until there is little or nothing left (knowledge. wharton.upenn.edu). Research suggests that $33 \%$ of customers entering a store leave without buying because such shoppers who experienced a problem and could not find sales help when they required assistance. Every day, $6 \%$ of all shoppers are lost due to lack of sales associate availability (Baker Retail Initiative, 2007). Such statistics highlight lost sales opportunities due to undersizing as retailers spend a substantial amount oftheir budget on marketing activities to draw customers to their stores.

However, such myopic behavior of reducing workforce size to save on the compensation cost of the retail workforce might affect store performance over the long run. When store managers reduce payroll expenses significantly- either by reducing the number of employees at the stores or reducing the number of hours worked - the amount of workload per employee increases. With the increased workload, store employees are more likely not to conform to designed processes. They are also likely to make more errors in performing their tasks, cannot serve the needs of customers effectively, become overstretched, and increase employee turnover. A higher level of store employee turnover seriously hinders efficient and effective customer service and thereby can cause customer dissatisfaction and undermine retails' competitiveness (Aliosha et al., 2007).

Part-time hourly retail store employees havea $76 \%$ turnover rate in 2019 , the highest of all positions (Korn Ferry, 2019). Employee turnover is associated with decreased retail store performance, as measured by profit margin and customer service. An increase of one standard deviation in employee turnover leads to a reduction of $0.5 \%$ in average customer service score and a $2.41 \%$ decrease in average profit margin (Ton \& Huckman, 2008). However, low employee turnover leads to increased customer satisfaction, loyalty, and retention (Madhani, 2021b). The researchers, after studying 41 stores of one retail chain, found stores to be understaffed about $41 \%$ of the time, and there is a decline of $1.95 \%$ in conversion when the store is understaffed. During peak hours, the stores were understaffed $68.21 \%$ of the time, and removing understaffing would lead to a sales lift of $7.21 \%$. The average lost sales due to understaffing during peak hours are calculated to be $8.56 \%$. The average profitability of retailers will increase by $7.02 \%$ if it eliminates understaffing during peak hours (Mani et al., 2015). Understaffing also negatively impacts store associate satisfaction and a decline in employee satisfaction has been linked to a decline in the store's financial performance (Maxham et al., 2008).

\section{Retail Workforce Oversizing Issues}

Increasing retail workforce size at an understaffed store is associated with higher conformance quality and service quality and leads to profit increases (Ton, 2009). However, if retailers hire too many store associates and the sales forecast is not realized, then at some point, they must take the unpleasant step of reducing the workforce size by layoff and downsizing, thereby lowering the morale of remaining 
store employees. With oversizing of the workforce, store associates probably are not challenged, the compensation and benefit costs of maintaining the store associates will be too high, and the profit of the retailer will be less. Hence, retailers typically take a conservative approach and view the consequences of larger workforce size as being more serious than those of keeping a smaller workforce.

\section{Traditional Retail Workforce Sizing Approach: Major Limitations}

The traditional retail workforce sizing method is based on the selling expenses approach. This method for determining retail workforce staffing is sales-driven and depends on store budget allocation. If a retail store has an annual sales volume of $\$ 400,000$ and its business plan recommends staff costs not exceed $10 \%$ of sales, then the amount of payroll dollars is approximately $\$ 769$ each week. Such a percentage of sales approach sets average retail workforce cost as a constant percentage of forecasted retail store sales. Such a selling expenses approach tends to be a rough method for determining some basic information about the retail workforce. However, this approach has various limitations as explained below:

1. The traditional retail workforce sizing approach is not effective with the changing needs of customers as it focuses on past sales. However, shopper demand may be different from past sales, as past sales include only customers who purchased and not those who had an intention to purchase but left the store due to poor service experience (i.e., lack of store associate assistance or service).

2. Retailers typically use a traditional workforce sizing approach to keep their costs under control, but this method fails to recognize the direction of causality between store sales and retail workforce size. A retail workforce drives store sales and not vice versa. Hence, setting retail store workforce costs to a percentage of sales is circular and fails to take into account how the store workforce impacts sales.

3. The traditional workforce sizing approach emphasizes maintaining the constant workforce cost to retail sales ratio. However, when the workforce cost to sales ratio is maintained by cutting headcount during a period of lower sales, the impact on profitability will be positive only if the retail workforce is already too large. In most cases, it will negatively impact store performance in long term.

4. Retailers can't reach their full potential if they follow traditional workforce sizing practice, because the scheduled workforce may not be enough to accommodate retail store customer traffic flows. As retail sales are also affected (among other factors) by store traffic, this sales-driven retail workforce staffing policy might result in labor-to-traffic-mismatches that can harmthe future sales revenue of retail store (Perdikaki et al., 2012).

5. The traditional retail workforce sizing approach is simplistic and relies too much on store managers' judgment based on their intuition or experience. Hence, some stores can provide exceptional customer service and a relaxed pace of work for employees, while at other stores, stressed-out workers struggle to meet their service-level targets. Hence, this approach does not give consistent performance across various retail stores (Laubli et al., 2015).

6. Traditional retail workforce sizing practices have negative short-term and long-term implications for retail store performance. This typical sales-based staffing rule leads to a vicious circleas most retailers don't know how to determine the optimal amount of staffing for individual stores. This approach ignores the simple fact that store employees drive sales. For every dollar a retailer saves on staffing costs, it may be losing several dollars in revenues and gross margin if customers leave a store empty-handed because they can't find a knowledgeable employee to help them. This can create a downward spiral in which fewer associates lead to poor customer service, which causes a further decline in revenues and another round of workforce cuts. In the worst case, this approach leads to a spiraling effect: a low sales forecast leads to reducing the retail workforce that leads to lower sales, and so on. 


\section{RESEARCH METHODOLOGY}

The retail workforce is a sales generator as well as a cost generator, influencing not only the compensation cost of the workforce but also the opportunity cost of lost sales associated with the retail store. The retail workforce investment issue affects staffing costs, the level of service quality offered to shoppers, and ultimately the profit of the retailer. Most retailers view the workforce as a cost, not an asset. As workforce compensation costs constitute one of the largest components of retailers' operating costs, there is a widespread tendency to understaff to save on those costs. Hence, there is a need to find the right number of store employees to provide consistent customer service even during the period of volatile store traffic. Decisions about retail workforce sizing involve a trade-off: additional cost of store employees (i.e., variable expenses for employee compensation and benefits - a known present cost) - against the incremental sales (i.e., revenue impact - an unknown future benefit) that would result from retail workforce staffing decision.

With optimal retail workforce sizing, customers would get prompt sales assistance and service, shelves replenished promptly, store employees would be neither idle nor overstretched and compensation costs managed effectively. Retail workforce optimization keeps store employees happy, improves customer service, and reduces opportunity costs of lost sales. A happy and engaged store associate is more than likely to provide better-quality and loyalty-strengthening customer interactions. The best in-store experience of customers can improve the conversion rate of the store. Better customer service viz. personalized advice, and deep product knowledge offered by the retail workforce could be a point of differentiation for retailers. As explained earlier, the traditional retail workforce sizing approach has certain inherent limitations. Hence, this research develops ananalytical workforce sizing approach and underscores the importance of optimal retail workforce size.

\section{Analytical Workforce Sizing Approach}

This approach states that new store associates need to be added until the gross profit on new business is equal to the cost of deploying another store associate. Hence, the retailer adds store employees until the increased contribution equals the incremental cost. This incremental approach is rigorous for calculating retail workforce size as it quantifies the important relationships between workforce size, revenue, and costs. However, there is a limit to the number of staff that can be added before stores reach a point of diminishing returns. The study of apparel chain stores revealed that the retailer's stores were achieving $85-95 \%$ of their potential sales with current staffing levels. However, with optimal staffing levels, the retailer could achieve $99 \%$ of potential sales. The study found that store managers were systematically understaffing their stores. If they even slightly increased staffing levels, they would generate incremental sales that would outweigh the labor costs (Oliva, 2017).

The retailer should conduct a break-even analysis for measuring workforce ROI (as calculated in Table 1 for the given illustration) to check if its workforce is of the right size. Follow five steps given below to conduct the retail workforce sizing analysis:

1. Estimate the annual cost of a retail store employee (C), the gross margin (GM), and the gross margin rate (GMR). The annual cost of a store employee includes all costs that vary with the number of store employees, including salary, benefits, bonuses, and taxes:

$\mathrm{GM}=$ Revenue $(\mathrm{R})-$ Variable product costs $(\mathrm{VC})$

$\operatorname{GMR}(\%)=\mathrm{GM} / \mathrm{R}$

2. Calculate break-even sales(B) (i.e. the amount a store employeegenerates in a year to cover his or her costs):

$\mathrm{B}=\mathrm{C} / \mathrm{GMR}$ 
3. Estimate the incremental revenue for additional store employee (I) (i.e. revenue an additional store employee could generate in a year). Incremental annual revenue per additional store employee will be less than the average annual revenue per current store employee because of the diminishing return on additional store employee effort.

4. Calculate break-even ratio (BER) (The ratio reflects the extent to which an additional store employee will generate revenue to cover his or her costs in a year):

$\mathrm{BER}=\mathrm{I} / \mathrm{B}$

For example, a ratio of 3 implies that, on average, a new store employee will generate gross margin equal to thrice his or her cost within a year.

5. Determine ROI on a store employee:

$\mathrm{ROI}=[($ The gross margin on the incremental revenue that an additional store employee can generate) - (The annual cost of an additional store employee) / (The annual cost of an additional store employee)]

The result is expressed as a percentage as per the formula given below:

$\mathrm{ROI}=[(\mathrm{GMR} \times \mathrm{I})-\mathrm{C}] / \mathrm{C}$

The above formula can be simplified as given below by substituting the value of GMR and I found earlier:

$\mathrm{ROI}=(\mathrm{C} / \mathrm{B}) \times(\mathrm{B} \times \mathrm{BER})-\mathrm{C}] /(\mathrm{C})$

$\mathrm{ROI}=\mathrm{BER}-1$

If ROI is too high compared to historical ROI, it shows that the workforce is undersized (i.e., understaffing) and employee compensation expenses are low. However, If ROI is too low compared to historical ROI, it shows that the workforce is oversized (i.e., overstaffing) and employee compensation expenses are high. For a right-sized workforce, ROI (and overall employee compensation costs) will not be too low or high but falls within an acceptable range (Figure 3(A)).

This analysis is corroborated by calculating the shopper-to-associate ratio (STAR) as it correlates the number of potential shoppers in the store and the number of associates who can meet those shoppers' needs. STAR (defined as the ratio of customer traffic to store labor hours) indicates the retail service level being provided by comparing the number of store employees on the floor at a given time to the number of shoppers in the retail store. Using store traffic data to plan store workforce staffing helps retailers to find the most suitable STAR. Very high STAR indicates understaffing, while low STAR indicates overstaffing (Figure 3(A)).

To figure out how many additional retail associates to hire, the basic approach for calculating the number of retail associates needed to reach the point of profit maximization is adding employees till marginal cost exceeds marginal revenue. Such a top-down approach calculates the contribution and cost associated with adding each store employee and then adds store employees for a retailer until the increased contribution equals the incremental cost (as calculated in Table 1 for the given illustration). While an additional store workforce can increase store profits through increased sales, it can reduce 
store profits due to increased workforce expenses as well. Certainly, there is a limit to the number of staff that can be added beforestores reach a point of diminishing returns (Oliva, 2017). Hence, retailers have to walk afine line between balancing the costs and benefits of the store workforce.

Figure 3. Analytical Retail Workforce Sizing Approach for Enhancing Store Performance (Source: Framework developed by the author)

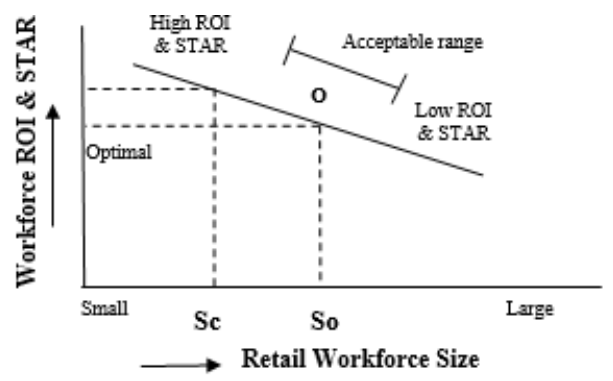

\section{Figure (A): Optimal Workforce ROI \& STAR}

$\mathrm{O}=$ Optimal Workforce ROI \& STAR

So $=$ Optimal workforce size

$\mathrm{Sc}=$ Current workforce size (understaffing)

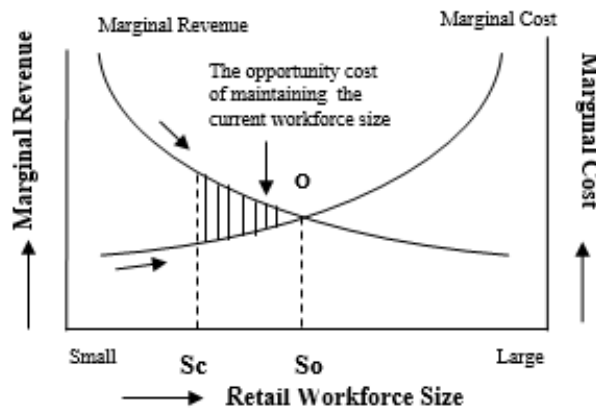

Figure (B): Incremental Approach

$\mathrm{O}=$ Breakpoint

So $=$ Optimal workforce size

$\mathrm{Sc}=$ Current workforce size (understaffing)

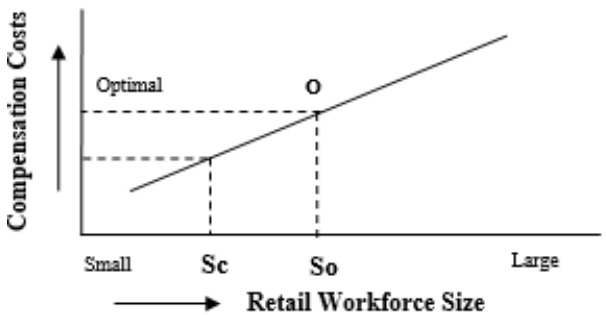

Figure (C): Optimal Compensation Costs

$\mathrm{O}=$ Optimal compensation costs

So $=$ Optimal workforce size

$\mathrm{Sc}=$ Current workforce size (understaffing)

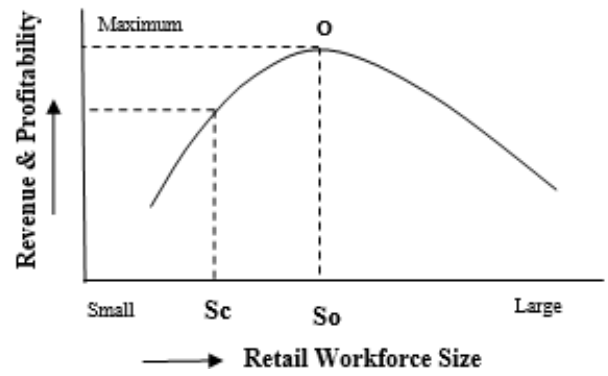

Figure (D): Maximum Revenue \& Profitability

$\mathrm{O}=$ Maximum revenue $\&$ profitability

So $=$ Optimal workforce size

$\mathrm{Sc}=$ Current workforce size (understaffing)

\section{Illustration}

In this hypothetical illustration, let's assume that the originally a beauty industry retailer (Beauty, Cosmetic \& Fragrance store) has 14 store associates and a fully loaded store associate costs (including 
salary, benefits, bonuses, and taxes) $\$ 85,000$ per associate. This represents a store associate cost ratio of 14.9 percent, in line with management guidelines (Table 1). According to the traditional workforce sizing approach, the current sizing of 14 sales associates seems adequate (cost containment approach). However, with this size of the workforce, ROI (303\%) and STAR (12.5\%) remain high while conversion rate remains low (30\%) against preferred target values (calculated based on data analytics). Hence, these calculations (Table 1) suggest that the existing retail workforce is undersized (Figure 3(A)). To determine the total number of associates to be added, an incremental approach has been used (Figure 3(B)). New store associates need to be added until marginal revenue per associate will be $\$ 85,000$, which is equal to the marginal cost of an additional associate (i.e., $\$ 85,000$ ).

Hence, six new store associates are required to be added to the existing retail workforce (understaffed) to get optimal workforce size (Table 1). This workforce expansion results in a higher conversion rate and profitability. The store associates cost ratio has increased, but so have profits as a result of increasing the retail workforce size (profit maximization approach). The main problem with the cost-containment approach is that it misconstrues the store associates' role. As the retail workforce is expanded, incremental revenue increases slowly at first and accelerate over time as the new workforce gets training, become acclimatized to their jobs, and enhances customer satisfaction by providing better services. In the case of retail workforce undersizing, when a retailer decides to increase the size of the workforce, the additional workforce not only generates incremental revenue with better conversion but also has a positive impact on workforce morale as the workforce is not overstretched. It also results in higher motivation as well as retention ofthe retail workforce. Improved retail workforce retention leads to lower hiring and training costs and improved store performance.

There is a point at the peak of the profit curve where the retail workforce size is maximizing profits. As shown in Figure 3(C), compensation costs increase with an increase in the size of the retail workforce; however, there is optimal ROI, STAR, and workforce size (So) where the profitability of the retailer is maximum. Retailer's profit will be maximum at optimal retail workforce size (So) (Figure 3(D)). With understaffing of the retail workforce, compensation costs are low with higher ROI and STAR but the profitability of the retailer is also low due to customer dissatisfaction and lost opportunities. On the other hand, with the overstaffing of the retail workforce, compensation costs are high, and hence ROI, STAR, and profitability of the retailer will be lower (Figure 3).

\section{RESEARCH CONTRIBUTIONS, LIMITATIONS, AND DIRECTIONS FOR FUTURE RESEARCH}

\section{Research Contributions}

As the retail environment is described as dynamic and highly competitive with a low-profit margin, retailers consider managing workforce costs as a key driver of their growth and profitability. In this exercise, retailers closely monitor market opportunity and workforce size to manage workforce compensation costs. The store traffic indicates the level of market opportunity available to a retailer. Retail workforce sizing is not a simple task for retailers, since the primary goal of workforce sizing strategy was not simply to minimize workforce capacity or compensation costs but also to build more productive and effective retail store operations.

Retailers often need to choose between increasing profits (profit maximization approach) and containing store workforce compensation costs (cost containment approach). When new store associates are added, they initially generate a small increase in revenue as well as profit and on the contrary increases employee cost to sales ratio. However, as time goes by, their impact gets bigger, as newly hired sales associates are not as effective as they will be when they become experienced. The right workforce sizing in the retail store leads to a shopping experience that is satisfying for customers and profitable for retailers. As shown in the illustration, with cost containment approach, beauty industry retailer was able to control store associates cost ratio (i.e. 14.9\%) by keeping it undersized 
(14 associates). However, with the profit maximization approach, the workforce was expanded (from 14 to 20 associates) to increase sales and profit (Table 1).

The research has identified two types of sizing errors in a retail setting: undersizing error and oversizing error (Figure 4).

Table 1. Calculations for Optimal Retail Workforce Sizing and Increased Profitability

\begin{tabular}{|c|c|c|c|c|c|c|c|c|c|}
\hline \multirow{2}{*}{$\begin{array}{l}\text { Sr. } \\
\text { No. } \\
(1)\end{array}$} & \multirow[b]{2}{*}{ The initial number of store associates } & \multirow{2}{*}{$\begin{array}{l}\begin{array}{c}\text { Base Case } \\
\text { (A) }\end{array} \\
14\end{array}$} & \multicolumn{6}{|c|}{ Intermediate Case (Addition of Retail Store Associates) (B) } & \multirow{2}{*}{$\begin{array}{c}\begin{array}{c}\text { Final } \\
\text { Case } \\
(\mathbf{C})\end{array} \\
14\end{array}$} \\
\hline & & & - & - & - & - & - & - & \\
\hline (2) & Incremental addition of store associates & - & 1 & 2 & 3 & 4 & 5 & 6 & - \\
\hline (3) & Revenue per store associate (\$) (annual) & 0.571 & 0.509 & 0.440 & 0.369 & 0.300 & 0.240 & 0.142 & 0.500 \\
\hline (4) & Final retail workforce size & 14 & \multicolumn{6}{|l|}{6} & 20 \\
\hline (5) & Retail store revenue (\$) (annual) & 8 & \multicolumn{6}{|l|}{2} & 10 \\
\hline (6) & Average revenue per store associate $(\$)=(5) /(4)$ & 0.571 & \multicolumn{6}{|l|}{0.333} & 0.500 \\
\hline (7) & Gross margin $(\%)$ & \multicolumn{8}{|l|}{60} \\
\hline (8) & Contribution per store associate $(\$)=(3) \times(7)$ & 0.343 & 0.305 & 0.264 & 0.221 & 0.180 & 0.144 & 0.085 & 0.300 \\
\hline (9) & Compensation cost of store associate (\$) (annual) & \multicolumn{8}{|l|}{0.085} \\
\hline (10) & Marginal contribution $(\$)=(8)-(9)$ & 0.258 & 0.220 & 0.179 & 0.136 & 0.095 & 0.059 & 0.000 & 0.215 \\
\hline (11) & Incremental cost $(\$)=(9) /(3)$ & 0.149 & 0.167 & 0.193 & 0.230 & 0.283 & 0.354 & 0.600 & 0.170 \\
\hline (12) & Break-even sales $(\$)=(9) /(7)$ & 0.142 & 0.142 & 0.142 & 0.142 & 0.142 & 0.142 & 0.142 & 0.142 \\
\hline (13) & Break-even ratio $(\mathrm{BER})=(3) /(12)$ & 4.034 & 3.593 & 3.106 & 2.605 & 2.118 & 1.694 & 1.000 & 3.529 \\
\hline (14) & ROI $(\%)=[(13)-1] \times 100$ & 303.36 & 259.29 & 210.59 & 160.47 & 111.76 & 69.41 & 0.00 & 252.94 \\
\hline (15) & Average daily store traffic & \multicolumn{8}{|l|}{174} \\
\hline (16) & Shopper-to-associate ratio $($ STAR $)=(15) /(4)$ & 12.5 & - & - & - & - & - & - & 8.75 \\
\hline (17) & Number of daily transactions & 52 & - & - & - & - & - & - & 87 \\
\hline (18) & Sales conversion ratio $(\%)=(17) /(15)$ & 30 & - & - & - & - & - & - & 50 \\
\hline (19) & Store associates cost ratio $(\%)=(9) /(6)$ & 14.9 & \multicolumn{6}{|l|}{25.5} & 17 \\
\hline (20) & $\begin{array}{l}\text { Increase in store associate cost ratio }(\%)= \\
{\left[\left(\mathrm{C}_{19}\right)-\left(\mathrm{A}_{19}\right)\right] /\left(\mathrm{A}_{19}\right)}\end{array}$ & - & \multicolumn{6}{|l|}{-} & 2.1 \\
\hline (21) & Net contribution $(\$)=(10) \times(4)$ & 3.612 & \multicolumn{6}{|l|}{0.689} & 4.301 \\
\hline$(22)$ & Increase in profitability $(\%)=\left[\left(\mathrm{C}_{21}\right)-\left(\mathrm{A}_{21}\right)\right] /\left(\mathrm{A}_{21}\right)$ & & \multicolumn{6}{|c|}{ 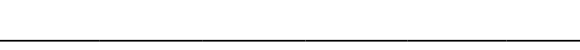 } & 19 \\
\hline (23) & Retail workforce size status & Understaffed & \multicolumn{6}{|c|}{ Retail workforce size increased } & Optimal \\
\hline
\end{tabular}

*All finance figures are expressed in Millions US\$

(Source: Calculated by the author)

\section{Undersizing Error}

The cost containment approach by a retailer sometimes leads to the undersizing of the retail workforce and hence results in a substantial forfeiture of future sales and profits. To rectify undersizing error (also called type II error) the retailer will have to enhance its workforce size to increase the effectiveness of the workforce with better service delivery. By understanding the opportunity within a store, retailers can more accurately manage their workforce to provide better services to customers, increase retail store sales, and grow profit. With an analytical workforce sizing approach developed in the research, the retailer needs to increase workforce size to achieve optimal retail workforce size (Figure 4). As shown in the illustration, the retailer has removed type II error (undersizing error) with optimal workforce size by increasing workforce size from 14 to 20 . 
Figure 4. Retail Workforce Sizing: Undersizing versus Oversizing Errors (Source: Matrix developed by the author)

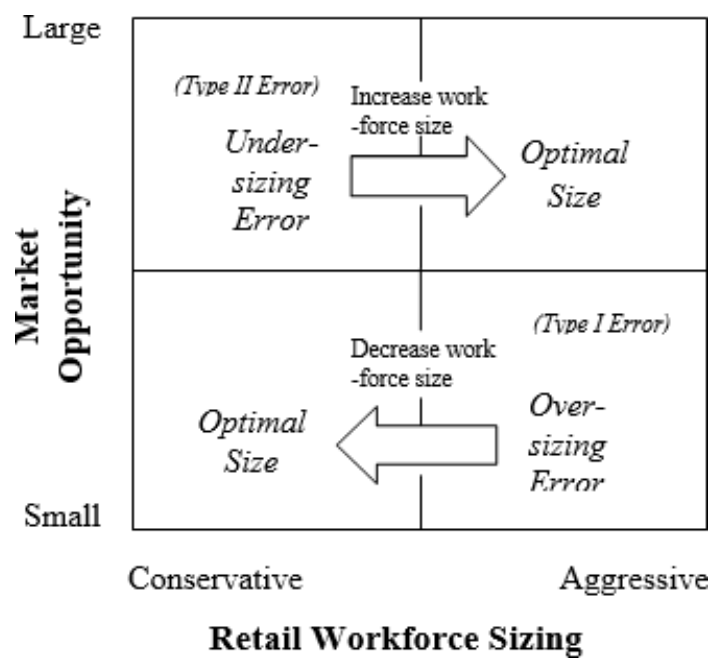

\section{Oversizing Error}

The sales enhancement approach by a retailer sometimes leads to the oversizing of the retail workforce and hence results in higher employee costs and many other issues. Having an excess of the retail workforce on the shop floor can be just as problematic as having too few. Retail store employees are also more likely to be disengaged if they're standing around with little to do or no customers to help - a systemic problem that hurts retail store employee retention. To rectify overstaffing error (also called type I error) the retailer will have toreduce its workforce size to increase the efficiency of the workforce and reduce the workforce payroll cost. With an analytical workforce sizing approach developed in the research, the retailer needs to decrease workforce size to achieve optimal retail workforce size (Figure 4).

\section{Limitations}

It is hard for retailers to isolate the effect of the retail workforce from all the other effects that might cause retail sales to go up or down and hence impact the store performance. These effects include pricing, advertising, sales promotions, along with changes in the distribution network, customer needs, and competitive behavior. Hence, all these control variables need to be monitored for establishing the relationship between retail workforce size and store performance.

\section{Directions for Future Research}

There are various retail formats (stores), such as grocery stores; specialty, apparel, and convenience stores; discount, entertainment, and quick-service restaurants. Retail stores offer a very wide range of goods, staple and changing fashion goods, from clothing to homeware, from accessories to furniture or white goods, often also food including fresh food. Because of the wide variations of retail service delivery, the role of retail associates will also be different. Hence, future research may focus on understanding and comparing the role of retail workforce sizing across various retail formats. 


\section{CONCLUSION}

Retail workforce staffing decisions are important for a retailer as consequences of such decision errors are likely to affect the retailer not just in the current year but for many years to come. Management of retail workforce is a key factor and, if implemented correctly, can act as a catalyst in synergizing the efforts of store workforce, leading to many positive outcomes for the retailer in terms of increased revenue, optimal compensation cost, and enhanced profitability. Undersizing of the retail workforce may hurt retailers in the long run as it affects merchandising capability and customer services, which ultimately hurt store sales and profits. The research works in this direction to develop an analytical workforce-sizing framework for calculating the optimal size of the retail workforce and provides calculation methodology. The analytical approach is appropriate and robust, as it tends to require more detailed analysis and rigor. Research also discusses the impact of the retail workforce sizing on the revenue and profitability of retail stores. When retailers closely looked at store activities and took a more data-driven and analytical approach to workforce sizing as suggested in this research, it leads to increased store profit while also improving customer service. Research also underscores the various issues related to retail workforce sizing - undersizing issues (type II error) and oversizing issues (type I error) and provides a methodology to overcome it. 


\section{REFERENCES}

A staggering amount of U.S. retail stores closed in 2017. (2018). https://stock-sector.com/a-staggering-amountof-u-s-retail-stores-closed-in-2017/

Aliosha, A., Babakus, E., \& Yavas, U. (2007). The effects of perceived management concern for frontline employees and customers on turnover intentions. Journal of Service Research, 9(4), 356-371. doi: $10.1177 / 1094670507299378$

Arndt, A., Arnold, T. J., \& Landry, T. D. (2006). The effects of polychronic-orientation upon retail employee satisfaction and turnover. Journal of Retailing, 82(4), 319-330. doi:10.1016/j.jretai.2006.08.005

Baker Retail Initiative. (2007). Shoppers at risk: An annual study of retail dissatisfaction. Executive Summary. The Wharton School, University of Pennsylvania.

Bapat, D., \& Thanigan, J. (2016). Exploring relationship among brand experience dimensions, brand evaluation and brand loyalty. Global Business Review, 17(6), 1357-1372. doi:10.1177/0972150916660401

Chuang, H. H., \& Oliva, R. (2015). Labor effects on retail data quality. Working Paper. Mays Business School. Texas A\&M University, College Station, TX.

Dana, D. Jr, \& Petruzzi, N. C. (2001). The news vendor model with endogenous demand. Management Science, 47(11), 1488-1497. doi:10.1287/mnsc.47.11.1488.10252

DeHoratius, N., \& Raman, A. (2007). Store manager incentive design and retail performance: An exploratory investigation. Manufacturing \& Service Operations Management, 9(4), 518-534. doi:10.1287/msom.1060.0150

DeHoratius, N., \& Ton, Z. (2015). The role of execution in managing product availability. In Retail Supply Chain Management (pp. 53-77). Springer.

Fisher, M., Gallino, S., \& Netessine, S. (2018). Setting retail staffing levels: A methodology validated with implementation. Working paper, Wharton School, Philadelphia.

Fisher, M., \& Raman, A. (2010). The New Science of Retailing. Harvard Business Press.

Fisher, M. L., Krishnan, J., \& Netessine, S. (2007). Retail store execution: An empirical study. Working paper, University of Pennsylvania: Philadelphia.

Fowler, D. C., Wesley, S. C., \& Vazquez, M. E. (2007). Simpatico in-store retailing: How immigrant Hispanic emic interpret US store atmospherics and interactions with sales associates. Journal of Business Research, 60(1), 50-59. doi:10.1016/j.jbusres.2006.09.002

Grewal, D., \& Levy, M. (2007). Retailing research: Past, present, and future. Journal of Retailing, 83(4), 447-464. doi:10.1016/j.jretai.2007.09.003

Heskett, J. L., Jones, T. O., Loveman, G. W., Sasser, W. E., \& Schlesinger, L. A. (1994). Putting the serviceprofit chain to work. Harvard Business Review, 72(2), 164-174.

Ifie, K. (2014). Customer orientation of frontline employees and organizational commitment. Service Industries Journal, 34(8), 699-714. doi:10.1080/02642069.2014.886197

InMoment. (2017). Retail trends report, why human interaction and the in-store experience still matter. http:// info.inmoment.com/rs/463-JAW-587/images/InMoment_Report_RetailTrends_Nov2017.pdf

Kim, J. E., \& Kim, J. (2012). Human factors in retail environments: A review. International Journal of Retail \& Distribution Management, 40(11), 818-841. doi:10.1108/09590551211267593

Korn Ferry Survey of Top US Retailers Examines Employee Turnover. (2019). https://www.kornferry.com/ about-us/press/as-the-holiday-shopping-season-approaches-korn-ferry-survey-of-top-US-retailers-examinesemployee-turnover

Korschun, D., Bhattacharya, C. B., \& Swain, S. D. (2014). Corporate social responsibility, customer orientation, and the job performance of frontline employees. Journal of Marketing, 78(3), 20-37. doi:10.1509/jm.11.0245 
Laubli, D., Schlégl, G., \& Silén, P. (2015). Smarter schedules, better budgets: How to improve store operations. Perspectives on Retail and Consumer Good, McKinsey \& Company, (August), 1-5.

LEK Consulting. (2017). Executive insights, rising labor costs - and what retailers can do about them. https:// www.lek.com/sites/default/files/insights/pdf-attachments/1916_Retail_Labor_Costs_LEK_Executive_Insights. pdf

Madhani, P. M. (2019). Rewards strategy: A key driver of service-profit chain. Compensation and Benefits Review, 51(4), 162-172. doi:10.1177/0886368719898310

Madhani, P. M. (2020). Performance optimisation of retail industry: Lean six sigma approach. ASBM Journal of Management, 13(1), 74-91.

Madhani, P. M. (2021a). Deploying 'Good Jobs' strategy in service sectors for enhancing competitive advantages. International Journal of Business Strategy and Automation, 2(1), 29-53. doi:10.4018/IJBSA.20210101.oa3

Madhani, P. M. (2021b). The rewards value chain: Optimal mix of tangible and intangible rewards for enhancing business performance. The Journal of Total Rewards, 30(2), 43-52.

Madhani, P. M. (2021c). Enhancing retail stores' performance: Managing compensation costs with optimal retail workforce sizing. The IUP Journal of Business Strategy, 18(1), 7-21.

Mani, V., Kesavan, S., \& Swaminathan, J. M. (2015). Estimating the impact of understaffing on sales and profitability in retail stores. Production and Operations Management, 24(2), 201-218. doi:10.1111/poms.12237

Maxham, J. G. III, Netemeyer, R. G., \& Lichtenstein, D. R. (2008). The retail value chain: Linking employee perceptions to employee performance, customer evaluations, and store performance. Marketing Science, 27(2), 147-167. doi:10.1287/mksc.1070.0282

MIT Study. (2017). MIT Sloan study finds holiday sales could increase with better staffing decisions by retailers. https://mitsloan.mit.edu/press/mit-sloan-study-finds-holiday-sales-could-increase-better-staffing-decisionsretailers

Netessine, S., Fisher, M. L., \& Krishnan, J. (2010). Labor planning, execution: and retail store performance: An exploratory investigation. Working paper. The Wharton School, University of Pennsylvania.

Oliva, R. (2017). Opinion: Retailers are leaving money on the table by understaffing. Marketwatch. https://www. marketwatch.com/story/retailers-are-losing-lots-of-money-by-understaffing-2017-12-18

Oliva, R., \& Sterman, J. D. (2001). Cutting corners and working overtime: Quality erosion in the service industry. Management Science, 47(7), 894-914.

Park, Y. H., Park, C. H., \& Gaur, V. (2010). Consumer Learning, Word of Mouth, and Quality Competition. Johnson School of Cornell University.

Perdikaki, O., Kesavan, S., \& Swaminathan, J. M. (2012). Effect of retail store traffic on conversion rate and sales. Manufacturing \& Service Operations Management, 14(1), 145-162.

PWC. (2016). Total Retail Survey. https://www.pwc.com/gx/en/retail-consumer/publications/assets/total-retailglobal-report.pdf

Rajamma, R. K., Paswan, A., \& Ganesh, G. (2007). Services purchased at brick and mortar versus online stores, and shopping motivation. Journal of Services Marketing, 21(3), 200-212.

Raman, A., DeHoratius, N., \& Ton, Z. (2001). Execution: The missing link in retail operations. California Management Review, 43(3), 136-152.

ReportR. D. (2017). https://www.retaildive.com/news/retailers-are-understaffing-stores-and-losing-sales/513055/

Retail's big mistake: Slashing payroll cuts into profits. (2019). https://knowledge.wharton.upenn.edu/article/ retail-staffing-model

Salesforce. (2019). Third edition, State of the Connected Customer. https://c1.sfdCtatic.com/content/dam/web/ en_us/www/assets/pdf/salesforce-state-of-the-connected-customer-report-2019.pdf 
Tang, C., Liu, Y., Ohc, H., \& Weitz, B. (2014). Socialization tactics of new retail employees: A pathway to organizational commitment. Journal of Retailing, 90(1), 62-73.

Ton, Z. (2009). The effect of labor on profitability: The role of quality. Working Paper: Harvard Business School.

Ton, Z. (2012). Why 'Good Jobs' are good for retailers. Harvard Business Review. https://hbr.org/2012/01/ why-good-jobs-are-good-for-retailers

Ton, Z., \& Huckman, R. S. (2008). Managing the impact of employee turnover on performance: The role of process conformance. Organization Science, 19(1), 56-68.

Ton, Z., \& Raman, A. (2010). The effect of product variety and inventory levels on retail store sales: A longitudinal study. Production and Operations Management, 19(5), 546-560.

US Census. (2020). Quarterly retail e-commerce sales report. www.census.gov/retail/mrts/www/data/pdf/ ec.current.pdf

Walton, S., \& Huey, J. (1993). Sam Walton, Made in America: My Story. Bantam.

Wiles, M. (2007). The effect of customer service on retailers' shareholder wealth: The role of availability and reputation cues. Journal of Retailing, 83(1), 19-31.

Williams, J. C., Kesavan, S., \& McCorkell, L. (2018). Research: When retail workers have stable schedules, sales, and productivity go up. Harvard Business Review. https://hbr.org/2018/03/research-when-retail-workershave-stable-schedules-sales-and-productivity-go-up

Young, J. (2020). US e-commerce sales grow by $14.9 \%$ in 2019. https://www.digitalcommerce360.com/article/ us-ecommerce-sales/ 
Pankaj M. Madhani earned a bachelor's degree in chemical engineering and law, a master's degree in business administration from Northern Illinois University, a master's degree in computer science from Illinois Institute of Technology in Chicago, and a Ph.D. in strategic management from CEPT University. He has more than 32 years of corporate and academic experience in India and the United States. During his tenure in the corporate sector, he was recognized with the Outstanding Young Managers Award. He is now working as associate dean and professor at ICFAI Business School (IBS). He has received the Best Research Paper Award at the IMCON-2016 International Management Convention. He has published various management books and more than 300 book chapters and research articles in several refereed journals. He is also conferred as the 'Best Professor in Strategy and Finance' by 'AMP Academic Excellence Award 2019' for his academic and research contributions. He also served as an editor of The IUP Journal of Corporate Governance. 